\title{
Suspension by winter storms has an energetic cost for adult male benthic harpacticoid copepods at a shelf site
}

\author{
David Thistle*, Georges L. Weatherly, Ann Wonnacott, Stephen C. Ertman \\ Department of Oceanography, Florida State University, Tallahassee, Florida 32306-3048, USA
}

\begin{abstract}
In the laboratory, we mimicked suspension of harpacticoid copepods by winter storms and measured the relative amount of neutral lipid per individual. The energy reserves of adult males decreased significantly after only $2 \mathrm{~d}$ of suspension. The energy reserves of adult females could not be shown to decrease even after $3 \mathrm{~d}$ of suspension. As storms lasting 2 to $3 \mathrm{~d}$ are common at the northern Gulf of Mexico study site $\left(29^{\circ} 40.63^{\prime} \mathrm{N}, 84^{\circ} 22.80^{\prime} \mathrm{W}\right)$, an energetic cost of suspension for adult male harpacticoids should be incorporated into explanation's of the effects of winter storms.
\end{abstract}

KEY WORDS: Harpacticoids · Storms · Suspension · Shelf $\cdot$ Benthos

\section{INTRODUCTION}

Winter storms are one of the most conspicuous features of the environment on temperate and boreal continental shelves. They can occur several times per month (Cacchione et al. 1987), have large spatial scales, and can move sediment at substantial water depths (e.g. Sherwood et al. 1994). Despite their potential importance, the effects of storms on the ecology of shelf benthic communities are only beginning to become known (Eagle 1975, McCall 1977, Shackley \& Collins 1984), particularly for meiofauna (Hogue 1982).

Shelf meiofauna tend to be concentrated in the upper few centimeters of sediment (de Bovée \& Soyer 1974, Huys et al. 1986), the layer subject to mobilization and transport (i.e. the creation of bed forms) by storms. Because these marine animals are small and have a specific gravity not much greater than that of seawater, they risk erosion when bottom shear forces increase (Palmer \& Gust 1985), e.g. during storms, unless they escape into the seabed. However, Thistle et al. (in press) found they do not escape below the reworked layer during even a moderate storm. When

•E-mail: thistle@ocean.fsu.edu eroded, they will be suspended rather than moved in bed-load transport. A suspended individual's energy costs in the water column may exceed its energy intake because many benthic meiofauna feed by scraping microbes from sediment particles (Wieser 1953, Itô 1970, Marcotte 1977), which they may be unable to do or may do with reduced efficiency in the water column (but see Decho 1986).

We investigated the possibility that being suspended entailed a cost that would be revealed as a decrease in the stored-energy reserves of suspended individuals. We chose the harpacticoid copepods as a representative study group because they range in lifestyle from infaunal burrowers to epibenthic forms (Noodt 1971, Coull 1972, Bell et al. 1987), encompassing much of the variability in lifestyle of the meiofauna.

\section{MATERIALS AND METHODS}

The study site was in the northern Gulf of Mexico $\left(29^{\circ} 40.63^{\prime} \mathrm{N}, 84^{\circ} 22.80^{\prime} \mathrm{W}\right)$ at $18 \mathrm{~m}$ depth (Fig. 1), where two $10 \mathrm{~m}$ lines placed $3 \mathrm{~m}$ apart defined the sampling area. The sediment was an unvegetated, medium sand with $<1 \%$ silt-clay content by weight. During winter, the water column was stratified; an 


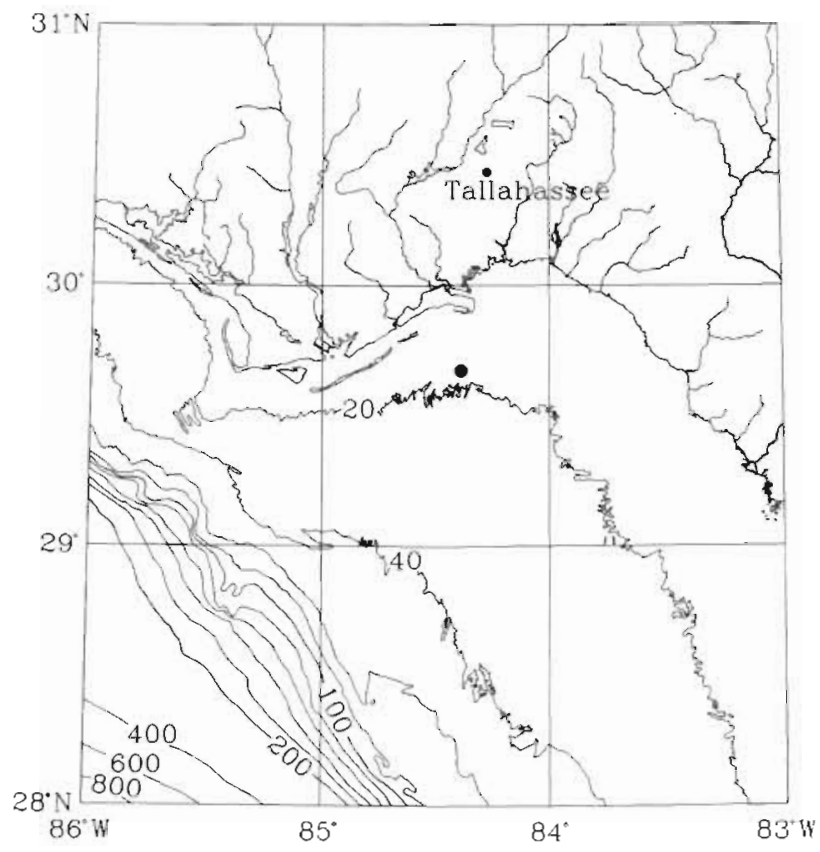

Fig. 1. Chart of the Gulf of Mexico off northern Florida, USA. Solid circle offshore indicates the location of the study site. Contours are in meters

approximately $8 \mathrm{~m}$ thick, colder, fresher layer overlay an approximately $10 \mathrm{~m}$ thick, warmer, saltier layer (Harkema et al. 1991, 1992, 1993).

To design the experiment, we needed information on the frequency and duration of winter storms, defined as periods when near-bottom flow velocities were sufficient to mobilize and transport the sediment at the study site and, therefore, had the potential to suspend harpacticoids. Our approach involved several types of field measurements. We deployed a long-term, burstsampling current meter at the study site during the winters of 1990, 1991, and 1992 (Harkema et al. 1991, 1992, 1993). The current meter consisted of a Savonius rotor (centered at $1 \mathrm{~m}$ above bottom), a vane, an internal compass, and an inclinometer. Current velocity, current direction, and the tilt of the current meter were recorded every $15 \mathrm{~min}$ in $32 \mathrm{~s}$ sampling bursts. To estimate storm frequency and duration, we examined the noisiness of the current-meter vane [specifically the vane-normalized unit vector (VNUV) (cf. Butman et al. 1979)]. From comparisons of periods when the VNUV was low and variable (i.e. when the vane record was very noisy) with weather maps and with wind and temperature data from nearby weather stations, it was apparent that sustained periods of low, noisy VNUV coincided with the passage of cold fronts and that the vane noisiness was caused by wave-induced current oscillations at the bottom. These data were correlated with sediment mobilization and transport as follows.
Several times while the long-term current meter was deployed, we also deployed a short-term (10 d duration) mooring with Savonius rotors centered at 8.0,4.5, $3.8,2.8,2.0,1.0,0.58$, and $0.24 \mathrm{~m}$ above bottom to provide measurements of near-bottom speed profiles. We estimated the bottom roughness parameter $z_{0}$ by fitting the data to the logarithmic speed profile equation (viz. the law of the wall) with a least squares fit (Harkema et al. 1991). The $z_{0}$ values calculated prior to the passage of cold fronts were consistent with those of a flat, rough bottom for which $z_{0}$ scales with sediment grain size, whereas $z_{0}$ values calculated for several days after the passage of cold fronts were consistent with the length scales associated with a rippled bottom. [Savonius rotors are poor sensors for accurate speed measurements during periods of strong surface-wave activity (e.g. Saunders 1980 ), so $z_{0}$ values calculated during the passage of a front were not considered reliable.] The post-front values indicated that during front passage (when VNUV was noisy) surface waves of sufficient height and period to create bedforms existed (Cacchione \& Drake 1990).

We confirmed this correlation between VNUV noisiness, wave statistics, and sediment mobilization and transport by deploying a time-lapse video recorder (50 $\mathrm{cm}$ above bottom) and a pressure sensor $(10 \mathrm{~cm}$ above bottom) at the site. Observation of particle motion in the video record showed 6 to $7 \mathrm{~s}$ oscillations of the near-bottom flow and initial motion of the sediment surface as the VNUV noisiness approached our defined storm threshold, and wave-generated bottom ripples were observed in the video record after the passage of cold fronts. These bedforms were smoothed out over several days by biological activity. The pressure record showed that when surface gravity waves with a $7 \mathrm{~s}$ period exceeded a height of $2 \mathrm{~m}$, visibility on the video record was completely obscured by sediment thrown into suspension by wave-induced reworking. Our inference received further support from hindcast estimates of the climatological wave field in the region (Hubertz \& Brooks 1989), which indicated that 7 s surface waves with heights $\geq 2 \mathrm{~m}$ occurred with approximately the same frequency as did storms as we defined them (G. L. Weatherly \& D. Thistle unpubl.). Storms occurred on average every $8.6 \mathrm{~d}$ during winter (December to March). On average, $75 \%$ of the storms lasted $>1 \mathrm{~d}, 42 \%$ lasted $>2 \mathrm{~d}$, and $17 \%$ lasted $>3 \mathrm{~d}$ (Table 1).

To determine the effect of suspension by winter storms on the stored-energy reserves of harpacticoids, we created a treatment that approximated conditions during winter storms (suspension) and a control treatment that approximated conditions in winter during calm periods (nonsuspension). For both treatments and controls, we used shear-driven annuli (Fukuda \& Lick 
Table 1. Statistics of storms at the study site between 1 December and 31 March (except for 1991 when measurements began on 11 December)

\begin{tabular}{|c|c|c|c|c|c|c|c|}
\hline Winter & Number of storms & $\begin{array}{c}\text { Minimum } \\
\text { (h) }\end{array}$ & $\begin{array}{c}\text { Maximum } \\
\text { (h) }\end{array}$ & $\begin{array}{c}\text { Average } \\
\text { (h) }\end{array}$ & $24 \mathrm{~h}$ & $\begin{array}{l}\text { ercent } \\
48 \mathrm{~h}\end{array}$ & $72 \mathrm{~h}$ \\
\hline 1990 & 13 & 10 & 126 & 49.6 & 77 & 46 & 15 \\
\hline 1991 & 17 & 10 & 96 & 44.5 & 82 & 47 & 18 \\
\hline 1992 & 12 & 5 & 112 & 39.8 & 67 & 33 & 17 \\
\hline
\end{tabular}

1980). Each was a circular tank (inner diameter = $45.8 \mathrm{~cm}$ ) with a central pillar (outer diameter $=12 \mathrm{~cm}$ ) (Fig. 2). Each annulus was filled with seawater (see below) to $10.1 \mathrm{~cm}$, creating a 'donut'-shaped volume of 15.5 l. A drive plate rested on the surface of the seawater. For the suspension condition, the average rotation rate of the drive plate was $147 \pm 8$ (SD) rev $\mathrm{min}^{-1}$. For the nonsuspension condition, a core was mounted in each annulus with the sediment surface coplanar with the bottom of the annulus. The drive plate was rotated at $12 \pm 0$ (SD) rev $\mathrm{min}^{-1}$; the water was moving, but the sediment at the surface of the core was not.

The experiment was replicated 4 times (runs) during winter 1992. A run consisted of 6 conditions, 1 condition per annulus. That is, 1 suspension annulus and 1 nonsuspension annulus were set up for each of 3 durations: $5 \mathrm{~min}(0 \mathrm{~d}), 48 \mathrm{~h}(2 \mathrm{~d})$, and $72 \mathrm{~h}(3 \mathrm{~d})$. The $0 \mathrm{~d}$ duration was a handling control. The $2 \mathrm{~d}$ and $3 \mathrm{~d}$ durations were chosen because $2 \mathrm{~d}$ and $3 \mathrm{~d}$ storms were frequent at the study site (Table 1). For each run, the 6 experimental conditions were randomly assigned to the 6 annuli. The temperature in the annuli was kept at the temperature of the bottom water at the site on the day the run was begun. We used daylight fluorescent bulbs mounted over each annulus to mimic the light intensity and light-dark cycle at the study site in winter at the midpoint of the bottom layer as measured by an in situ recording light meter. We chose this depth because, given the stratification, the suspended harpacticoids would be largely confined to the bottom layer during storms.

On the day each run was begun, 6 seawater samples were collected from the site at the midpoint of the bottom layer with a $30 \mathrm{l}$ Niskin bottle (Teflon-covered spring, silicone O-rings). As a check on the availability of microalgae that could be food for harpacticoids in the water (Decho 1986), we took two $250 \mathrm{ml}$ samples from each volume for chlorophyll a (chl a) concentration determination (following Evans \& O'Reilly 1983 and Lohrenz et al. 1988). To remove large, planktonic herbivores that might deplete the phytoplankton during a run, we sieved each volume through a mesh of $243 \mu \mathrm{m}$.

For each run, seven $15.5 \mathrm{~cm}^{2}$ cores were taken at random from the site by divers. One core was selected at random to be an at-sea control. The harpacticoids were extracted from the top $3 \mathrm{~cm}$ of sediment of the atsea control by decantation (Pfannkuche \& Thiel 1988). In our implementation of decantation, we placed the sediment and the overlying water in a graduated cylinder and made the volume up to $1 \mathrm{l}$ with $32 \mu \mathrm{m}$ filtered seawater. We inverted the cylinder 5 times in quick succession, set it upright for $10 \mathrm{~s}$, and poured approximately $70 \%$ of the fluid off into a sieve. We repeated the procedure 5 times. Harpacticoids were extracted with $>95 \%$ efficiency ( $n=3)$. We sampled the top $3 \mathrm{~cm}$ of each core because the seabed at the study site is subject to mobilization and transport to this depth during winter storms (Thistle et al. in press). The extracted material was caught on a $63 \mu \mathrm{m}$ mesh sieve, frozen with liquid nitrogen, and stored at $-18^{\circ} \mathrm{C}$. The remaining cores were transported to the laboratory at approximately in situ temperature under subdued light. Each core was assigned at random to 1 of the 6 experimental conditions (e.g. 0 d nonsuspension).

In the suspension treatment, we wished to approximate the concentration of harpacticoids and materials that the harpacticoids would experience when suspended during a storm. We did so by extracting the overlying water and top $3 \mathrm{~cm}$ from the appropriate core by decantation (the decanted fluid was poured directly into the appropriate annulus) because decantation removed from the sediment those materials (e.g.

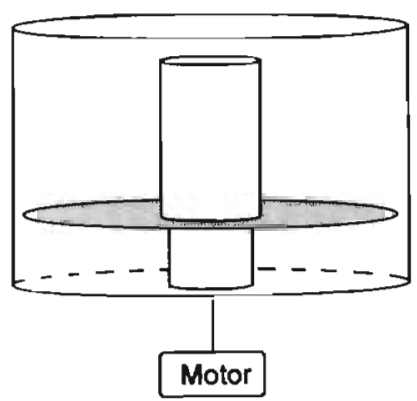

Fig. 2. Schematic representation of an annulus used in the suspension treatment. The annuli used for the nonsuspension treatment differed only by the addition of a core mounted such that the surface of the sediment was coplanar with the bottom of the annulus 
Table 2. Harpacticoid fauna. Because the harpacticoid fauna of our site was largely undescribed, each individual was assigned to a numbered working species. The taxonomic affinities of the working species were determined with the aid of Wells' (1977) key and the primary literature and are given below. Ectinosomatidae were omitted from the study because of taxonomic difficulties. The species whose adult males were tested are indicated (atested in $2 \mathrm{~d}$ datai ${ }^{b}$ tested in $3 \mathrm{~d}$ data), and their abundance rank among the tested species is given

\begin{tabular}{|c|c|c|c|c|}
\hline \multirow[t]{2}{*}{ Working species } & \multirow[t]{2}{*}{ Family } & \multirow[t]{2}{*}{ Species } & \multicolumn{2}{|c|}{ Abundance rank } \\
\hline & & & $2 d$ & $3 d$ \\
\hline $201^{d, b}$ & Laophontidae & Paralaophonte brevirostris & 10 & 14 \\
\hline 203 & Cletodidae & Enhydrosoma cf. littorale & & \\
\hline $204^{d, b}$ & Leptastacidae & Leptastacus cf. coulli & 6 & 3.5 \\
\hline 205 & Thalestridae & Paradactylopodia sp. & & \\
\hline $206^{a, b}$ & Ameiridae & Nitocra sp. & 7 & 7 \\
\hline 210 & Parastenhelidae & Parastenhelia cf. ornatissima & & \\
\hline $220^{a, b}$ & Diosaccidae & Robertgurneya sp. & 1 & 1 \\
\hline 222 & Longipediidae & Longipedia sp. & & \\
\hline 223 & Canthocamptidae & cf. Mesochra & & \\
\hline 229 & Canuellidae & Coullana canadensis & & \\
\hline $232^{a, b}$ & Diosaccidae & Robertsonia cf. knoxi & 2 & 2 \\
\hline 234 & Tetragonicipitidae & Phyllopodopsyllus sp. & & \\
\hline $235^{a}$ & Diosaccidae & Robertsonia sp. A & 5 & 3.5 \\
\hline $236^{\mathrm{ab} b}$ & Canthocamptidae & cf. Mesachra & 13 & 12 \\
\hline $237^{a, b}$ & Diosaccidae & cf. Robertgurneya & 8 & 8.5 \\
\hline 238 & Thalestridae & cf. Dactylopodia & & \\
\hline $239^{b}$ & Cylindropsyllidae & New genus & - & 8.5 \\
\hline $240^{a \cdot b}$ & Laophontidae & Pholenota cf. spatulifera & 4 & 6 \\
\hline $241^{\mathrm{b}}$ & Ameiridae & Praeleptomesochra sp. & - & 12 \\
\hline $244^{a, b}$ & Diosaccidae & Amphiascoides sp. & 3 & 5 \\
\hline $245^{\mathrm{a}, \mathrm{b}}$ & Thalestridae & Diarthrodes sp. & 11.5 & 12 \\
\hline $247^{a}$ & Ameiridae & Ameira of. listensis & 11.5 & - \\
\hline 248 & Ameiridae & cf. Nitocra & & \\
\hline 249 & Diosaccidae & Actopsyllus sp. & & \\
\hline 250 & Ameiridae & Leptomesochra sp. & & \\
\hline 251 & Diosaccidae & Stenhelia sp. & & \\
\hline 253 & Diosaccidae & Stenhelia cf. peniculata & & \\
\hline $255^{\mathrm{a}, \mathrm{b}}$ & Diosaccidae & Bulbamphiascus cf minutus & 9 & 10 \\
\hline 256 & Cylindropsyllidae & Paraleptastacus sp. & & \\
\hline
\end{tabular}

fine sediment) with settling velocities less than or equal to those of harpacticoids, which are the materials that the harpacticoids would experience while suspended during a storm. To create the correct concentration of harpacticoids and these materials in the annulus, we assumed that mixing of suspended material during a storm would be limited to the bottom $10 \mathrm{~m}$ of the water column because of the stratification. Therefore, the harpacticoids and material extracted from the $3 \mathrm{~cm}$ by $15.5 \mathrm{~cm}^{2}$ sediment column would be suspended into a volume $15.5 \mathrm{~cm}^{2} \times 10 \mathrm{~m} \mathrm{(=} 15.5 \mathrm{l}$ ) during a storm. By adding $243 \mu \mathrm{m}$ filtered seawater from the study site to the annulus to make the volume 15.5 l, we approximated this aspect of conditions at our site during a storm. To sample a suspension treatment, we siphoned two $250 \mathrm{ml}$ samples for chl a concentration determination while the drive plate was rotating. We then removed the drive plate and siphoned the remaining water through a $62 \mu \mathrm{m}$ mesh sieve. The sieve contents were frozen with liquid nitrogen and stored at $-18^{\circ} \mathrm{C}$.
To establish a nonsuspension treatment, we mounted the appropriate core in an annulus, such that the sediment surface was coplanar with the annulus bottom, and added $15.5 \mathrm{l}$ of $243 \mu \mathrm{m}$ filtered seawater without disturbing the sediment. To prevent development of anoxia in the core, we allowed seawater to percolate through it at $0.13 \mathrm{ml} \mathrm{min} \mathrm{m}^{-1}$. The core was observed hourly; at no time did we detect the change in sediment color indicative of anoxia (Rhoads 1974), although we had seen this color change deeper in cores from the study site. To sample a nonsuspension treatment, we took two $250 \mathrm{ml}$ water samples for chl a measurements and siphoned the remaining water from the annulus. The core was removed, and the top $3 \mathrm{~cm}$ were extracted by decantation onto a $62 \mu \mathrm{m}$ mesh sieve. The sieve contents were frozen and stored as above.

To assess the energy reserves of harpacticoids, we measured the relative amount of stored neutral lipid per adult harpacticoid following Carman et al. (1991). Briefly, harpacticoids were removed from the thawed 
sample under a dissecting microscope. Each adult was stained in a solution of the lipid-specific fluorochrome Nile red (Kodak) and identified (Table 2). Specimens were mounted in lateral view with the right side uppermost. Under epifluorescence illumination (excitation $525 \pm 25 \mathrm{~nm}, 545 \mathrm{~nm}$ dichroic mirror, emission $580 \pm$ $25 \mathrm{~nm}$ ), the neutral-lipid droplets (visible through the transparent body wall) in the half of the prosome toward the observer were brought into focus and photographed. Then the neutral-lipid droplets in the half of the urosome toward the observer were brought into focus and photographed as above. The photographic slides were mounted in an enlarger in a standard geometry. The neutral-lipid area $\left(\mathrm{cm}^{2}\right)$ of the enlarged image was measured with the aid of image analysis for each individual. (During neutral-lipid quantification, the identity of the sample was not known by the operators.) The neutral-lipid area for each individual was $\log _{10}(x+1)$ transformed (the transformed scale) to reduce the right skew of the raw data. Species represented by $\leq 5$ individuals were eliminated from the data set.

For statistical analysis, we separated the copepods into adult males and adult females (females with external egg sacs were omitted) because of the possibility that the energy demands of reproduction might make adult females respond differently from adult males to suspension. Our working hypothesis was that neutral lipids decreased during suspension for adult males taken as a class and for adult females taken as a class. Because the individuals from an annulus (a sample) were pseudoreplicates, we obtained a single observation for each sample as follows. For a given test, we determined the smallest number of individuals present in any of the samples. From each of the remaining samples, we selected that number of individuals at random without replacement and calculated a mean. We repeated the process 100 times and computed a mean of the means for each sample, which is the statistic that was used in subsequent calculations.

\section{RESULTS}

\section{Preliminaries}

To determine whether the concentration of microalgae decreased from natural levels during the experiment, we compared the concentration of chl a in the at-sea controls to the concentrations at the end for the $2 \mathrm{~d}$ and the $3 \mathrm{~d}$ durations (Table 3) separately with 1 -tailed $t$-tests. There was no indication of a significant de-crease in chl a concentration in either case.

To determine whether the amount of neutral lipid in suspension samples had been reduced prior to a run, we compared individuals from the samples most repre-
Table 3. Mean chlorophyll a concentration $\left(\mathrm{mg} \mathrm{m}^{-3}\right), \mathrm{n}=2$. At sea: measurements made on samples placed on ice immediately after collection. Start and End: measurements made on samples from the beginning and the end of a run respectively for the suspension treatment

\begin{tabular}{|llll|}
\hline Run & At sea & Start & End \\
\hline $0 \mathrm{~d}$ & & & \\
1 & 0.58 & 0.53 & 1.62 \\
2 & 0.82 & 0.83 & 1.18 \\
3 & 0.69 & 0.66 & 1.44 \\
4 & 0.83 & 0.75 & 1.92 \\
Mean & 0.73 & 0.69 & 1.54 \\
$2 \mathbf{d}$ & & & \\
1 & 0.60 & 0.55 & 1.19 \\
2 & 0.91 & 0.71 & 1.92 \\
3 & 0.78 & 0.67 & 1.80 \\
4 & 0.79 & 0.88 & 4.61 \\
Mean & 0.77 & 0.70 & 2.38 \\
3 d & & & \\
1 & 0.62 & 0.58 & 1.38 \\
2 & 0.82 & 0.83 & 1.56 \\
3 & 0.77 & 0.58 & 0.95 \\
4 & 0.88 & 0.89 & 3.12 \\
Mean & 0.77 & 0.72 & 1.75 \\
\hline
\end{tabular}

sentative of conditions in the field (the at-sea controls) to individuals from samples taken immediately after each run was set up ( 0 d suspension samples) (Table 4 ). For adult females, the means were equal; for adult males, the $0 \mathrm{~d}$ suspension mean was greater than the at-sea mean. These results indicate that the transport of the samples to the laboratory and the establishment of the experimental conditions did not introduce artifacts that could have confounded our conclusions, because the differences were small and in directions opposite to those of the hypotheses to be tested.

To determine whether neutral-lipid area changed over time in the nonsuspension (control) treatments, we calculated a 1-way ANOVA on neutral-lipid areas among at-sea, $0 \mathrm{~d}$ nonsuspension, $2 \mathrm{~d}$ nonsuspension, and 3 d nonsuspension samples for adult males and adult females separately. The overall ANOVA was not significant for either sex $(p>0.1)$. For each sex, the means were similar among conditions, with considerable overlap in the ranges. Therefore, there was no indication of a difference between neutral-lipid areas from values measured on individuals frozen as soon as possible after capture and those from material kept under nonsuspension (control) conditions for up to $3 \mathrm{~d}$.

\section{Main experiment}

After $2 \mathrm{~d}$ of exposure to storm-like treatments in the laboratory, the mean neutral-lipid area for adult 
females from the suspension treatment on the transformed scale was 0.98 . The mean neutral-lipid area for adult females in the nonsuspension treatment was 1.00 (Table 4), a difference that was not statistically significant ( $p>0.5,1$-tailed, paired t-test). A power calculation (Dixon \& Massey 1969) revealed that the test had a probability $>0.95$ of detecting a difference in mean neutral-lipid area between treatments as great as or greater than that found for adult males (see below).

For adult males, the mean neutral-lipid area in the $2 \mathrm{~d}$ suspension treatment on the transformed scale was 0.27 . The mean area in the nonsuspension treatment was 0.61 (Table 4 ). The difference was significant $(p<$ $0.01,1$-tailed, paired $t$-test). When the alpha level was adjusted by the Bonferroni method (Snedecor \& Cochran 1980) because 2 tests (adult males and adult females) were done, the result for the adult males remained significant. Although the test on neutrallipid area allowed us to detect an effect of suspension, the consequences of the change in neutral-lipid area for the biology of adult males can be more easily seen in terms of neutral-lipid volume because stored energy varies directly with the volume of neutral lipid. To estimate the change in neutral-lipid volume that an average individual might experience, we assumed that neutral-lipid droplets were spherical, that within a treatment all the droplets had the same radius, and that the number of droplets was the same in the average individual in both treatments. Under these assumptions, the change in area corresponded to a $76 \%$ decrease in neutral-lipid volume

Table 4. Harpacticoid copepods. Average amounts of projected neutral-lipid area $\left(\mathrm{cm}^{2}\right)\left[\log _{10}(x+1)\right.$ transformed] for adult females and adult males. Sus suspension treatment; Non: nonsuspension treatment. For females, the atsea and $0 \mathrm{~d}$ entries are based on 19 ind sample ${ }^{-1}$, and the $2 \mathrm{~d}$ and $3 \mathrm{~d}$ entries are based on 15 ind. sample ${ }^{-1}$ For adult males, the at-sea and 0 d entries are based on 14 ind. sample $e^{-1}$, the 2 d entry is based on 22 ind sample ${ }^{-1}$, and the $3 \mathrm{~d}$ entry is based on 7 ind. sample $e^{-1}$

\begin{tabular}{|c|c|c|c|c|c|c|c|}
\hline \multirow[t]{3}{*}{ Run } & \multirow[t]{3}{*}{ At sea } & \multicolumn{6}{|c|}{ Duration } \\
\hline & & \multicolumn{2}{|c|}{$0 \mathrm{~d}$} & \multicolumn{2}{|c|}{$2 \mathrm{~d}$} & \multicolumn{2}{|c|}{$3 d$} \\
\hline & & Sus & Non & Sus & Non & Sus & Non \\
\hline \multicolumn{8}{|c|}{ Females } \\
\hline 1 & 0.92 & 1.14 & 0.87 & 0.92 & 1.12 & 0.92 & 0.88 \\
\hline 2 & 0.69 & 0.75 & 0.93 & 0.79 & 0.83 & 0.65 & 1.19 \\
\hline 3 & 1.00 & 0.97 & 0.90 & 1.02 & 0.99 & 1.19 & 1.20 \\
\hline 4 & 1.20 & 0.94 & 0.93 & 1.20 & 1.07 & 1.15 & 1.22 \\
\hline Mean & 0.95 & 0.95 & 0.91 & 0.98 & 1.00 & 0.98 & 1.12 \\
\hline \multicolumn{8}{|l|}{ Males } \\
\hline 1 & 0.60 & 0.72 & 0.51 & 0.33 & 0.59 & 0.33 & 0.61 \\
\hline 2 & 0.47 & 0.54 & 0.50 & 0.17 & 0.74 & 0.30 & 0.48 \\
\hline 3 & 0.58 & 0.58 & 0.53 & 0.33 & 0.60 & 0.24 & 0.57 \\
\hline 4 & 0.46 & 0.54 & 0.44 & 0.24 & 0.52 & 0.21 & 0.95 \\
\hline Mean & 0.53 & 0.60 & 0.50 & 0.27 & 0.61 & 0.27 & 0.65 \\
\hline
\end{tabular}

After $3 \mathrm{~d}$ of suspension, there was no significant difference between the means of the suspension (0.98) and nonsuspension (1.12) treatments for adult females (1-tailed, paired t-test) (Table 4). A power calculation revealed that the test had a probability $>0.4$ of detecting a difference in mean neutral-lipid area between treatments as great as or greater than that found for adult males (see below).

For adult males, the mean neutral-lipid area in the $3 \mathrm{~d}$ suspension treatment on the transformed scale was 0.27 , while in the nonsuspension treatment, it was 0.65 . The former was significantly less than the latter ( $\mathrm{p}<$ $0.05,1$-tailed, paired $t$-test) (Table 4 ). When the alpha level was adjusted to take into account that 2 tests were performed, the result for the adult males remained significant. We estimated that the volume of neutral lipid decreased by $89 \%$.

Two statistical problems complicated extension of this analysis to adult males of individual species. First, samples contained different numbers of adult males of a given species. To reduce the number of individuals used to calculate the sample means to the lowest number of adult male individuals of a species found in any sample as above was not appropriate because most of the information about each species' response would be lost. Instead, we used all the individuals of a species in a sample to calculate a mean for the sample and accepted that this procedure makes the $t$-test conservative by introducing heterogeneity into the treatment variances (D. Meeter pers. comm.). In this sense, the list of species found to be significant is the minimum list. At the same time, the alpha level of each test was not adjusted to account for multiple testing, which could artificially increase the number of significant species. Therefore, the species-level results are only suggestive.

In the 2 d duration data, the adult males of 13 species could be tested (i.e. adult males were present in $>1$ run for one of the treatments and $\geq 1$ run for the other treatment). Of those species, 3 (23\%) had 'sıgnificantly' smaller neutral-lipid areas in the suspension treatment (Table 5). These species ranked second, seventh, and ninth in abundance in the $2 \mathrm{~d}$ duration data of the 13 species tested (Table 2), so the lack of significant differences in the other abundant species is unlikely to have arisen simply because of this aspect of statistical power. In the 3 d duration data, the adult males of 14 species could be tested, and the neutral-lipid areas of $5(36 \%)$ were 'significantly' smaller in the suspension treatment (Table 5). These species 
Table 5. Harpacticoid copepods. Average amount of projected neutral-lipid area $\left(\mathrm{cm}^{2}\right)\left[\log _{10}(x+1)\right.$ transformed] for each of the species that was 'significant' Non: nonsuspension treatment; Sus: suspension treatment

\begin{tabular}{|c|c|c|c|c|c|c|}
\hline \multirow[t]{2}{*}{ Species } & \multicolumn{3}{|c|}{$2 \mathrm{~d}$} & \multicolumn{3}{|c|}{$3 d$} \\
\hline & Non & Sus & $\mathrm{p}$ & Non & Sus & $\mathrm{p}$ \\
\hline Nitocra sp. & 1.17 & 0.23 & $<0.05$ & 0.65 & 0.17 & $<0.01$ \\
\hline Robertgurneya sp. & & & & 0.53 & 0.14 & $<0.025$ \\
\hline Robertsonia cf knoxi & 0.91 & 0.34 & $<0.025$ & 1.04 & 0.38 & $<0.005$ \\
\hline Robertsonia sp. A & & & & 0.42 & 0.16 & $<0.05$ \\
\hline cf. Robertgurneya & & & & 0.59 & 0.05 & $<0.005$ \\
\hline Bulbamphiascus cf. minutus & 0.68 & 0.19 & $<0.05$ & & & \\
\hline
\end{tabular}

ranked $1,2,3.5,7$, and 8.5 in abundance; again, the 'significant' species were not simply the most abundant.

A comparison of the $2 \mathrm{~d}$ and 3 d results shows that Nitocra sp. and Robertsonia cf. knoxi utilized large amounts of their neutral lipids sooner than did Robertgurneya sp., Robertsonia sp. A, and cf. Robertgurneya. The same may be true for Bulbamphiascus cf. minutus. The lack of significance in the $3 \mathrm{~d}$ data for Bulbamphiascus cf. minutus may be the result of a small sample size. The $2 \mathrm{~d}$ result was based on 11 individuals, whereas only 6 were available for the $3 \mathrm{~d}$ analysis.

\section{DISCUSSION}

\section{Preliminaries}

The bottom-associated, water-column feeding harpacticoids that have been studied consume microalgae (Decho 1986). As the chl a concentrations in the suspension annuli at the beginning of each replicate were very similar to those in the at-sea controls and to chl a values measured in near-shore waters in this area (Livingston 1984), the starting chl a concentrations in the suspension annuli were appropriate. Rather than declining during the runs, the chl a concentration increased. We cannot comment on changes in plant species composition during our experiment, but the chl a measurements indicate no shortage of plant biomass in the suspension annuli.

Comparison of the neutral-lipid areas in the at-sea samples to those in the $0 \mathrm{~d}$ nonsuspension samples suggests that transport of the cores from the field to the laboratory and the handling involved in setting up the experimental conditions did not affect harpacticoid neutral-lipid content in such a way as to bias our results. Also, the neutral-lipid areas of the nonsuspension samples showed no evidence of a decrease over time, suggesting that there was no deterioration in these control treatments that could have affected the results.
Ideally, neutral-lipid reserves would be measured as mass, but such measurements on individual benthic harpacticoids are at the limit of conventional analytic procedures (Carman et al. 1991). As information on individuals was of interest in this study, we used the Nile red technique (Carman et al. 1991), which can be used on individuals but measures neutral-lipid area rather than mass. Because only a relative measure was required, the Carman et al. (1991) technique was appropriate, but it was insensitive to small changes in mass or changes in mass that did not affect the outline of the neutral-lipid droplets in lateral view.

\section{Main experiment}

For adult male harpacticoids, mean neutral-lipid areas were significantly smaller in suspension than in nonsuspension treatments after $2 \mathrm{~d}$ and after $3 \mathrm{~d}$. We estimated that the differences corresponded to substantial decreases in the neutral-lipid volume of suspended adult males. Given that many storms at the study site suspend adult males for longer than $2 \mathrm{~d}$, the result suggests that storm-induced suspension has a large energetic cost. Whether this cost is compensated for by other consequences of being in the water column, such as dispersal, is not known.

In comparisons of the means of the at-sea, $0 \mathrm{~d}, 2 \mathrm{~d}$, and $3 \mathrm{~d}$ suspension samples for adult males, the $2 \mathrm{~d}$ mean was conspicuously smaller than the at-sea mean, but there was no corresponding difference between the $2 \mathrm{~d}$ and $3 \mathrm{~d}$ means, suggesting a decrease in the rate of neutral-lipid utilization between Day 2 and Day 3. Given that the number of species whose adult males had significantly reduced neutral-lipid areas increased between Day 2 and Day 3, the apparent decrease in rate of neutral-lipid utilization may or may not be real. That adult males suspended for 2 or $3 \mathrm{~d}$ have less neutral lipid than adult males in the sediment implies that while suspended they acquire energy at a lower rate, increase their energy use, or both. Although suspended adult males probably feed (if at 
all) at a lower rate than do adult males in the sediment, our results could arise by any combination of increased energy cost for or decreased energy supply to suspended adult males.

For adult females, mean neutral-lipid areas were not significantly less in suspension than in nonsuspension treatments after either 2 or $3 \mathrm{~d}$. The power analysis on the $2 \mathrm{~d}$ duration results suggested that it was very likely that we would have detected a decrease in neutral-lipid area as great as or greater than that found for adult males. The power analysis on the $3 \mathrm{~d}$ duration results revealed that we had a much smaller probability of detecting a decrease in neutral-lipid area greater than or equal to that found for adult males (because of greater variance of adult female neutral-lipid levels).

The results were not sufficient to reveal whether adult males used more of their neutral-lipid reserves than adult females while suspended. The difficulty arose because our methods more readily detected a change of a given amount when neutral-lipid volume was small than when it was large. As adult females contained more neutral lipid per individual on the average than did adult males, we would have more readily detected a difference in neutral-lipid utilization for adult males than for adult females. To examine this issue, we calculated (in the transformed space) the decrease in mean neutral-lipid volume (using the assumptions above) that would have been expected if suspended adult females had used as much neutral lipid on a volume basis as suspended adult males. We then converted the values back to an area basis. For both the $2 \mathrm{~d}$ and $3 \mathrm{~d}$ data, the nonsuspension values were significantly greater than these estimates, suggesting that if suspended adult females had used as much (or more) neutral lipid as the suspended adult males, we would have detected it. Therefore, we inferred that the difference in neutral-lipid utilization between suspended and nonsuspended individuals was greater for adult males than for adult females after 2 and $3 \mathrm{~d}$.

As adult males and adult females have similar mouth parts, they are unlikely to differ in ability to feed in the water column. Whether harpacticoids feed in the water column or not, our results suggest that suspended adult males utilized more neutral lipid relative to nonsuspended adult males than did suspended adult females relative to nonsuspended adult females. Therefore, it seems appropriate to search for the explanation of the asymmetry in neutral lipid usage in asymmetries between the biology of adult males and adult females.

First, adult males are often smaller (and therefore weigh less) than adult females (Hicks \& Coull 1983), but energy consumption increases with weight in most invertebrates (Vernberg \& Coull 1974), so metabolic consequences of the difference in size seem unlikely to underlie the results.

Second, adult males mate with subadult females (Hicks \& Coull 1983), so adult males actively seek mates, whereas adult females do not. If mating can occur in the water column (see Bell et al. 1988, 1989, Hicks 1988), the differences in neutral-lipid reserves could come about if adult males in the water column cannot feed sufficiently to 'pay' for the mating activities, that is, if males feed at a lower rate, or if mating activities are more energetically costly in the water column. Adult males should incur these costs if mating can only occur in the water column (Hicks 1988) or if an increase in the frequency of mate acquisition compensates in terms of fitness for the energy costs.

Although this explanation may be appropriate for slow-flow situations, it is unlikely to be so for storms because the swimming speeds of adult male harpacticoids should be comparable to those of the macrofaunal larvae studied by Butman (1986) (because of the similarity in size) and those are insufficient to allow directed swimming in the water column during storms. If the decrease of energy reserves we document results because adult males persist in attempting to find mates under conditions where that strategy cannot work, then the energy use would be maladaptive, and storms would be periods of energetic stress for adult male harpacticoids.

A third hypothesis arises from the possibility that turbulent water motions during storms might bring potential mates together passively. If encounters between potential mates occurred often enough, then energy an adult male invested in remaining poised to clasp a mate could be compensated for in fitness terms by an increase in mating frequency. If suspended adult males acquired energy much less rapidly than they used it, this scenario could produce the results we observed. We used coagulation theory (Jumars 1993) to calculate the frequency of encounters with potential mates that turbulence could bring about. Depending on assumptions about the height above bottom through which the harpacticoids are mixed, adult males of the most common species could encounter copepodite-5 females (i.e. potential mates) as often as several times per day, suggesting that this hypothesis should not be dismissed out of hand.

The difference between adult male and adult female neutral-lipid utilization while suspended could be accentuated if adult females had no reason to remain active, sensed they had been suspended, and reduced their metabolic rate to a level that could be met by feeding or, if feeding is impossible, to a level that makes negligible demands on stored energy. Reductions of metabolic rate are known for crustaceans, for example, torpor in deep-sea scavenging amphipods 
(Smith \& Baldwin 1982). Suspended adult females need not become torpid; simply by the cessation of feeding they could reduce their metabolic rate (Kiørboe et al. 1985). An ability of suspended adult females to reduce the rate at which they use their energy reserves could be adaptive because depleted neutral-lipid levels can interfere with reproduction (Tessier \& Goulden 1982, Clarke et al. 1985).

Finally, the presence of sediment-dwelling meiofauna in the water column has been known for some time (Hagerman \& Rieger 1981, Palmer \& Brandt 1981), and there has been considerable interest in the possible costs and benefits (Palmer 1988). Although evidence for benefits has been presented (Decho 1986, Service \& Bell 1987, Hicks 1988), the costs have not been assessed. Our results suggest that $2 \mathrm{~d}$ of suspension for adult females may involve little, if any, cost in terms of a depletion of stored energy reserves. If this effect is achieved without a reduction in metabolic rate, then suspension by storms may be benign in these terms, but if adult females reduce their metabolic rate when in the water column, then the rates of other processes (i.e. egg production) could be slowed. Therefore, it is premature to conclude that suspension is benign for adult females. For adult males, our results suggest that suspension by winter storms entails a large energetic cost and establish that there may be disadvantages for benthic harpacticoids in the water column. The harpacticoid results raise the possibility that suspension may involve energetic costs for other permanent (e.g. nematodes) and temporary (e.g. juvenile polychaetes) meiofauna.

Acknowledgements. D. Balkwill, R. Iverson, and P. LaRock advised on procedures and loaned equipment. D. Meeter and D. Burr-Doss gave statistical advice. S. Boa, D. Hunley, and J. Ritch helped in the field and laboratory. S. S. Bell, K. R. Carman, B. C. Coull, J. E. Eckman, B. T. Hentschel, P. A. Jumars, M. A. Palmer, and A. B. Thistle commented on versions of the manuscript. We are grateful for this help. The research was supported by NSF grant OCE-8911181 to D.T. and G.L.W. Contribution 1082 of the FSU Marine Laboratory.

\section{LITERATURE CITED}

Bell SS, Hicks GRF, Walters K (1988) Active swimming in meiobenthic copepods of seagrass beds: geographic comparisons of abundances and reproductive characteristics. Mar Biol 98:351-358

Bell SS, Hicks GRF, Walters K (1989) Experimental investigations of benthic re-entry by migrating meiobenthic copepods. J exp mar Biol Ecol 130:291-303

Bell SS, Walters K, Hall MO (1987) Habitat utilization by harpacticoid copepods: a morphometric approach. Mar Ecol Prog Ser 35:59-64

Butman B, Noble M, Folger DW (1979) Long-term observations of bottom current and bottom sediment movement on the Mid-Atlantic Continental Shelf. J geophys Res 84: $1187-1205$
Butman CA (1986) Larval settlement of soft-sediment invertebrates: some predictions based on an analysis of near-bottom velocity profiles. In: Nihoul JCJ (ed) Marine interfaces ecohydrodynamics. Elsevier, Amsterdam, p 487-513

Cacchione DA, Drake DE (1990) Shelf sediment transport: an overview with applications to the northern California continental shelf. In: Le Mehaute B, Hanes DM (eds) The sea. Wiley, New York, p 729-773

Cacchione DA, Grant WD, Drake DE, Glenn SM (1987) Storm-dominated bottom boundary layer dynamics on the northern California continental shelf: measurements and predictions. J geophys Res 92:1817-1827

Carman KR, Thistle D, Ertman SC, Foy M (1991) Nile red as a probe for lipid-storage products in benthic copepods. Mar Ecol Prog Ser 74:307-311

Clarke A, Skadsheim A, Holmes LJ (1985) Lipid biochemistry and reproductive biology in two species of Gammaridae (Crustacea: Amphipoda). Mar Biol 88:247-263

Coull BC (1972) Species diversity and faunal affinities of meiobenthic Copepoda in the deep sea. Mar Biol 14:48-51

de Bovée F, Soyer J (1974) Cycle annuel quantitatif du méiobenthos des vases terrigènes cotiéres. Distribution verticale. Vie Milieu (Ser B) 24:141-157

Decho AW (1986) Water-cover influences on diatom ingestion rates by meiobenthic copepods. Mar Ecol Prog Ser 33: $139-146$

Dixon WJ, Massey FJJ (1969) Introduction to statistical analysis. McGraw-Hill, New York

Eagle RA (1975) Natural fluctuations in a soft bottom benthic community. J mar biol Ass UK 55:865-878

Evans CA, O'Reilly JE (1983) A handbook for the measurement of chlorophyll $a$ in net plankton and nannoplankton. NOAA, National Marine Fisheries Service, Highlands, NJ

Fukuda MK, Lick W (1980) The entrainment of cohesive sediments in freshwater. J geophys Res 85:2813-2824

Hagerman GH Jr, Rieger RM (1981) Dispersal of benthic meiofauna by wave and current action in Bogue Sound, North Carolina, USA. PSZN: I Mar Ecol 2:245-270

Harkema R, Weatherly GL, Thistle DE (1991) A compilation of moored current meter data from the Big Bend region of the west Florida shelf November 1989-April 1990. Dept of Oceanography, Florida State University, Tallahassee

Harkema R, Weatherly GL, Thistle DE (1992) A compilation of moored current-meter data from the Big Bend region of the west Florida shelf November 1990-April 1991. Dept of Oceanography, Florida State University, Tallahassee

Harkema R, Weatherly GL, Thistle DE (1993) A compilation of moored current meter data from the Big Bend region of the West Florida Shelf December 1991-April 1992. Dept of Oceanography, Florida State University, Tallahassee

Hicks GRF (1988) Evolutionary implications of swimming behavior in meiobenthic copepods. Hydrobiol 167/168: 497-504

Hicks GRF, Coull BC (1983) The ecology of marine meiobenthic harpacticoid copepods. Oceanogr mar Biol A Rev 21: $67-175$

Hogue EW (1982) Sediment disturbance and the spatial distributions of shallow water meiobenthic nematodes on the open Oregon coast. J mar Res 40:551-573

Hubertz JM, Brooks RM (1989) Gulf of Mexico hindcast wave information. Wave information studies of United States coastlines, Report 16. US Army Corps of Engineers, Washington, DC

Huys R, Herman RL, Heip C (1986) Seasonal fluctuations in vertical distribution and breeding activity of a subtidal harpacticoid community in the Southern Bight, North Sea. Neth J Sea Res 20:375-383 
Itô T (1970) The biology of a harpacticoid copepod, Tigriopus japonicus Mori. J Fac Sci, Hokkaido Univ (Ser VI Zool) 17: $474-500$

Jumars PA (1993) Concepts in biological oceanography. Oxford University Press, Oxford

Kiørboe T, Møhlenberg F, Hamberger K (1985) Bioenergetics of the planktonic copepod Acartia tonsa: relation between feeding, egg production and reproduction, and composition of specific dynamic action. Mar Ecol Prog Ser 26: $85-97$

Livingston RJ (1984) The ecology of the Apalachicola Bay system: an estuarine profile. US Fish Wild Serv FSW/OBS 82/05, Washington, DC

Lohrenz SE, Wiesenburg DA, DePalma IP, Johnson KS, Gustafson DE Jr (1988) Interrelationships among primary production, chlorophyll, and environmental conditions in frontal regions of the western Mediterranean Sea. Deep Sea Res 35:793-810

Marcotte BM (1977) An introduction to the architecture and kinematics of harpacticoid (Copepoda) feeding: Tisbe furcata (Baird, 1837). Mikrofauna Meeresbod 61:183-196

McCall PL (1977) Community patterns and adaptive strategies of the infaunal benthos of Long Island Sound. J mar Res 35:221-266

Noodt W (1971) Ecology of the Copepoda. Smithson Contr Zool 76:97-102

Palmer MA (1988) Dispersal of marine meiofauna: a review and conceptual model explaining passive transport and active emergence with implications for recruitment. Mar Ecol Prog Ser 48:81-91

Palmer MA, Brandt RR (1981) Tidal variation in sediment densities of marine benthic copepods. Mar Ecol Prog Ser 4: $207-212$

Palmer MA, Gust G (1985) Dispersal of meiofauna in a turbulent tidal creek. J mar Res 43:179-210

Pfannkuche O, Thiel H (1988) Sample processing. In: Higgins $\mathrm{RP}$, Thiel $\mathrm{H}$ (eds) Introduction to the study of meiofauna.

This article was presented by J. M. Lawrence (Senior Editorial Advisor), Tampa, Florida, USA
Smithsonian Institution Press, Washington, DC, p 134-145

Rhoads D (1974) Organism-sediment relations on the muddy sea floor. Oceanogr mar Biol A Rev 12:263-300

Saunders PM (1980) Overspeeding of a Savonius rotor. Deep Sea Res 27:755-759

Service SK, Bell SS (1987) Density influenced active dispersal of harpacticoid copepods. J exp mar Biol Ecol 114:49-62

Shackley SE, Collins M (1984) Variations in sublittoral sediments and their associated macro-infauna in response to inner shelf processes; Swansea Bay, UK. Sedimentology 31:793-804

Sherwood CR, Butman B, Cacchione DA, Drake DE, Gross TE, Sternberg RW, Wiberg PL, Williams AJ III (1994) Sediment-transport events on the northern California continental shelf during the 1990-1991 STRESS experiment. Cont Shelf Res 14:1057-1062

Smith KL Jr, Baldwin RJ (1982) Scavenging deepsea amphipods: effects of food odor on oxygen consumption and a proposed metabolic strategy. Mar Biol 68: $287-298$

Snedecor GW, Cochran WG (1980) Statistical methods. The Iowa State University Press, Ames

Tessier AJ, Goulden CE (1982) Estimating food limitation in cladoceran populations. Limnol Oceanogr 27:707-717

Thistle D. Weatherly GL, Ertman SC (in press) Shelf harpacticoid copepods do not escape into the seabed during winter storms. J mat Res

Vernberg WB, Coull BC (1974) Respiration of an interstitial ciliate and benthic energy relationships. Oecologia 16: $259-264$

Wells JBJ (1977) Keys to aid in the identification of marine harpacticoid copepods. Zoology Department, University of Aberdeen, Aberdeen

Wieser W (1953) Die Beziehung zwischen Mundhöhllengestalt, Ernährungsweise und Vorkommen bei freilebenden marinen Nematoden. Ark Zool (Ser II) 4: $439-484$

Manuscript first received: November 29, 1994

Revised version accepted: March 14, 1995 